Volume 5 Issue 2, September 2020: pp. 122-134. Copyright @ LamLaj. Faculty of Law, Lambung Mangkurat University, Banjarmasin, South Kalimantan, Indonesia. ISSN: 2502-3136 | e-ISSN: 2502-3128. Open Access at: http://lamlaj.ulm.ac.id/web/

\title{
TAX AMNESTY BAGI WARGA NEGARA ASING (WNA) DI INDONESIA
}

\author{
Luluk Nurmalita $^{1}$, Indrawati ${ }^{2}$ \\ Fakultas Hukum Universitas Airlangga \\ Jalan Dharmawangsa Dalam Selatan, Surabaya, 60286, Indonesia \\ Email:queen.khadijah27@gmail.com \\ Fakultas Hukum Universitas Airlangga \\ Jalan Dharmawangsa Dalam Selatan, Surabaya, 60286, Indonesia \\ Email: indrawati_unair@yahoo.com
}

Submitted : 15/06/2020 Reviewed:20/09/2020 Accepted:24/09/2020

\begin{abstract}
Tax Amnesty which is an Indonesian government program should not only be followed by its citizens but also can be followed by Foreign Citizens. In order to achieve the objective of this program is to increase state revenues, mandatory taxes, the government must also increase the position of foreigners as taxpayers. This writing aims to provide an analysis related to the placement of foreigners as taxpayers and the application of Tax Amnesty that can be applied by foreigners as both individual taxpayers and those who have mixed marriages with Indonesian. The research method used is normative juridical with statutorye approaches and conceptual approaches. Based on the legal analysis in this study, it can be concluded that according to the principles of tax law, foreigners are taxpayers who can take part in Tax Amnesty and if a foreigner who is married to an Indonesian citizen and wants to participate in tax amnesty, then his marriage must have a property separation agreement.
\end{abstract}

Keywords: Intermarriage; Separate Assets; Tax Amnesty; Tax Law

Abstrak: Tax Amnesty merupakan program pemerintah Indonesia seharusnya tidak hanya dapat diikuti oleh warganya tetapi jug a dapat diikuti oleh Warga Negara Asing (WNA). Demi mencapai tujuan program ini yaitu untuk meningkatkan pendapatan negara khususnya disektor pajak, pemerintah juga harus memaksimalkan kedudukan WNA sebagai wajib pajak. Penulisan ini bertujuan untuk memberikan analisa hukum terkait kedudukan WNA sebagai wajib pajak dan penerapan Tax Amnesty yang dapat dilaksanakan WNA baik sebagai wajib pajak individu maupun yang telah 
melakukan perkawinan campuran dengan Warga Negara Indonesia. (WNI). Metode penelitian yang digunakan adalah yuridis normatif dengan pendekatan peraturan perundang-undangan (statutorye approach) dan pendekatan konsep (conceptual approach). Berdasarkan analisa hukum pada penelitian ini, maka disimpulkan bahwa menurut asas-asas hukum pajak, WNA merupakan wajib pajak yang dapat mengikuti Tax Amnesty dan jika WNA yang menikah dengan WNI dan ingin mengikuti pengampunan pajak, maka pernikahannya harus memiliki perjanjian pisah harta.

Kata Kunci: Hukum Pajak; Perkawinan Campuran; Perjanjian Pisah Harta; Tax Amnesty

\section{PENDAHULUAN}

Warga Negara Indonesia (WNI) dimanapun berada memiliki kewajiban membayar pajak. Pajak menjadi suatu hal yang penting dan wajib bagi masyarakat yang masih memiliki kewarganegaraan Indonesia. Hal ini bersifat konstitusional obligation ${ }^{1}$ yaitu sebagaimana diamanatkan didalam Pasal 23 A UUD 1945 bahwa pungutan yang bersifat memaksa diatur dengan Undang-Undang. Pajak merupakan pungutan memaksa yang berdampak pada semua orang dan tidak boleh tidak dilakukan. Menurut Rochmat Soemitro, pajak diartikan: ${ }^{2}$ "Pajak ialah iuran rakyat kepada kas negara (peralihan dari sektor swasta ke sektor pemerintah) berdasarkan Undang-undang (dapat dipaksakan) dengan tiada mendapat jasa timbal (tegen prestatie) yang langsung dapat ditunjuk untuk membiayai pengeluaran umum dan yang digunakan sebagai alat pencegah atau pendorong untuk mencapai tujuan yang ada di luar bidang keuangan".

Dapat dipaksakan artinya adalah bahwa bila hutang pajak tidak dibayar maka hutang itu dapat ditagih dengan menggunakan kekerasan, seperti surat paksa dan sita, dan juga penyanderaan terhadap pembayaran pajak.

\footnotetext{
1 Rochmat Soemitro, Asas dan DasarDasar Perpajakan (Bandung: PT. Eresco, 1990), 51

2 Ibid 5
}

Pajak merupakan salah satu pendapatan terbesar Negara. Meningkatnya pembangunan yang dilakukan suatu Negara, mengharuskan pula bertambahnya pendapatan Negara tersebut. ${ }^{3}$ Strategi meningkatkan penerimaan dilakukan oleh Pemerintah dengan meningkatkan kepatuhan kewajiban pajak. Kepatuhan wajib pajak menjadi faktor yang penting dalam penerimaan pendapatan Negara guna menunjang pembangunan. Oleh karena itu, pemerintah melakukan salah satu strategi peningkatan kepatuhan pajak bagi masyarakat yaitu dengan strategi penagihan pajak. Penagihan pajak yang dilakukan secara paksa terkesan menyeramkan karena masyarakat seperti "ditagih" atau memiliki hutang terhadap Negara. Dampak penagihan akan berujung pada penyitaan asset apabila setelah dilakukan konseling, surat peringatan dan surat paksa, tetapi wajib pajak masih belum menunjukkan itikad baik. Hal tersebutlah yang akhirnya membuat masyarakat terpaksa patuh untuk membayar pajak. Namun tidak sedikit yang akhirnya menyembunyikan asetnya di luar negeri demi menghindari kewajiban pajak di Indonesia.

\footnotetext{
3 Ramadhani Indah Sari and Dian Anita Nuswantara, "The Influence of Tax Amnesty Benefit Perception to Taxpayer Compliance" Jurnal Dinamika Akuntansi 9, no. 2 (2017): 176-183. https://journal.unnes.ac.id/ nju/index.php/jda/article/view/11991/7455
} 
Bank Indonesia dan Kementerian Tenaga Kerja dan Transmigrasi telah melakukan survey pada tahun 2009 terhadap WNA yang bekerja sebagai Tenaga Kerja Asing (TKA) di Indonesia. Survey tersebut menunjukkan bahwa, pada September 2009 tercatat ada 45.384 orang TKA yang bekerja di Indonesia. ${ }^{4}$ Sebagian besar menempati jabatan professional yaitu jabatan sebagai konsultan ahli yang kedudukannya sama dengan pegawai internal (pegawai tetap). Berdasarkan survey, sebanyak 56\% WNA bekerja di Indonesia karena penugasan, dan sebanyak 44\% karena keinginan sendiri. Mayoritas TKA sudah tinggal di Indonesia lebih dari 1 (satu) tahun yaitu sebanyak $83 \%$. Hal ini mengindikasikan bahwa TKA tersebut dikontrak untuk jangka waktu lebih dari 1 (satu) tahun masa kerja. Dari hasil survey tersebut sebagian besar TKA yang menjabat sebagai direktur memiliki gaji 50 juta sampai dengan 100 juta per bulan. Gaji tersebut selain untuk kebutuhan hidup di Indonesia dan menabung, 20\% dari gajinya juga mereka kirim ke Negara asal (remitansi). Para responden yang kesemuanya TKA juga memberikan masukan terkait peraturan pajak di Indonesia yang harus diperbaiki, pelayanan administrasi di sektor pemerintahan, dan penurunan tarif pajak untuk TKA. Keluhan TKA terkait tingginya tarif pajak dapat mengindikasikan faktor keengganan untuk melaporkan kewajiban pajaknya. Meskipun pada Pajak Penghasilan (PPh) sudah terpotong, akan tetapi potensi pajak yang dihasilkan dari asset TKA/WNA yang ada di Negara asalnya juga perlu diperhatikan. Jangan sam-

\footnotetext{
4 Noor Yudanto et al., "Survey Nasional Tenaga Kerja Asing di Indonesia Tahun 2009," Bank Indonesia, Bank Sentral Republik Indonesia, Last modified 2010, accessed August 1, 2020, https:// www.bi.go.id/id/publikasi/lain/lainnya/Pages/ SurveiTKAIndonesia_09.aspx
}

pai mereka bekerja dan berpenghasilan tinggi di Indonesia dan dikirim ke Negara asalnya untuk mendirikan usaha di sana, sedangkan hasil usahanya tidak dilaporkan sebagai kewajiban pajak di Indonesia.

Melalui tax amnesty, pemerintah Indonesia berharap dapat meningkatkan kepercayaan WNA untuk melaporkan asetnya. Program ini juga merupakan jembatan ketika nanti pemerintah menerapkan self assessment ${ }^{5}$ pajak yaitu dengan cara menumbuhkan kesadaran wajib pajak untuk melaporkan hartanya karena sistem ini pada prinsipnya memberikan hak kepada wajib pajak untuk menghitung sendiri pajak yang terutang olehnya. Selain itu, pemerintah melalui kebijakan Tax Amnesty ingin memaksimalkan potensi pajak yang ada baik yang tersimpan didalam negeri yang belum dilaporkan maupun asset yang berada di luar negeri. ${ }^{6}$

Kesadaran pelaporan harta seharusnya tidak hanya berlaku bagi WNI saja, tetapi WNA yang berada di Indonesia selama 183 hari dan dikategorikan sebagai wajib pajak wajib pula melaporkan hartanya baik yang berada di Indonesia maupun di Negara asalnya. Sebagian besar WNA yang berpenghasilan dari bekerja di Indonesia juga memiliki penghasilan di Negara asalnya. Misalkan, WNA Inggris yang bekerja sebagai tenaga ahli di Indonesia selama lebih dari 183 hari dan mendapatkan penghasilan menikah dengan WNI yang juga berpenghasilan. Namun, WNA Inggris tersebut juga memiliki apartemen di Inggris yang juga disewakan dan hasil

\footnotetext{
Rochmat Soemitro, Asas dan Dasar Perpajakan 2 (Bandung : PT Refika Aditama, 1998), 14.

6 Titik Setyaningsih and Antin Okfitasari, "Mengapa Wajib Pajak Mengikuti Tax Amnesty (Studi Kasus di Solo)," Stiesia: Jurnal Ekonomi dan Keuangan 20, no. 4 (2016): 430, https://ejournal.stiesia.ac.id/ ekuitas/article/view/2012/38
} 
sewa tersebut dikirim ke rekeningnya. Penghasilannya di Indonesia ia gunakan untuk melakukan perawatan apartemennya di Inggris. Hasil sewa apartemen tersebut harusnya dapat dilaporkan tetapi kebanyakan WNA menyembunyikan harta mereka tersebut dan hanya penghasilannya di Indonesia saja yang dilaporkan. Masalah lain akan timbul ketika pernikahan WNA dan WNI ini tanpa perjanjian pisah harta. Perkawinan campuran tanpa perjanjian pisah harta, maka dianggap harta yang diperoleh sebagai harta bersama. ${ }^{7} \mathrm{Hal}$ ini akan bermasalah ketika pelaporan pajak, petugas pajak akan menanyakan adakah perjanjian pisah harta, jika tidak maka WNI yang bertindak sebagai istri akan diminta memilik untuk mengikuti NPWP suami atau melakukan pelaporan sendiri.

Hal ini menjadi penting karena WNA yang berada di Indonesia juga diketahui beberapa memiliki aset di luar Indonesia bahkan menikah dengan WNI. Berdasarkan latar belakang tersebut muncul permasalahan yang akan dibahas antara lain:

1) Bagaimana penerapan Tax Amnesty bagi WNA berkaitan dengan kedudukannya sebagai wajib pajak?

2) Bagaimana penerapan Tax Amnesty bagi WNA yang menikah dengan WNI?

\section{METODE}

Metode penelitian yang tepat untuk digunakan didalam penulisan ini adalah metode penelitian hukum normatif. Didalam penelitian hukum normatif ini akan difokuskan pada pendekatan peraturan perundang-undangan

7 Dewi Mulyati, "Pelaksanaan Perjanjian Pemisahan Harta Dalam Perkawinan Warga Negara Indonesia Dengan Warga Negara Asing, " Jurnal IUS Kajian Hukum dan Keadilan Fakultas Hukum Universitas Mataram 5, no. 2 (2017): 9, http://jurnalius.ac.id/ ojs/index.php/jurnalIUS/article/view/460/ atau statutory approach dan pendekatan konsep atau conceptual approach. Statutory Approach merupakan pendekatan yang menggunakan hukum tertulis seperti undang-undang dan regulasi yang berkaitan dengan isu hukum yang akan dibahas secara mendalam. ${ }^{8}$ Pendekatan ini memfokuskan pendekatan bahan hukum primer berupa peraturan tertulis seperti peraturan perundang-undangan yang secara khusus mengatur tentang tax amnesty yang dikaitkan dengan peraturan hukum pajak dan peraturan perkawinan di Indonesia.

Conceptual Approach ${ }^{9}$ yaitu suatu konsep yang menitik beratkan pada penggunaan doktrin sarjana hukum ahli yang diakui dalam ilmu hukum yang khusus untuk memberikan panduan dan kejelasan didalam memahami permasalahan hukum terkait tax amnesty dan penerapannya terhadap harta perkawinan campuran.

Studi Kepustakaan atau studi dokumen merupakan teknik pengumpulan data yang digunakan didalam penelitian ini. Teknik ini berupa pengumpulan bahan-bahan hukum baik bahan hukum primer dan bahan hukum sekunder. Bahan hukum ini akan dianalisa menggunakan metode interpretasi sistematis, kemudian ditafsirkan dengan rumusan masalah penelitian terkait penerapan tax amnesty bagi Warga Negara Asing dan perkawinan campuran yang dilihat didalam perspektif hukum pajak.

\section{ANALISIS DAN PEMBAHASAN \\ Penerapan Tax Amnesty Terhadap Warga Negara Asing (WNA) Berkaitan dengan Kedudukannya Sebagai Wajib Pajak}

Program pengampunan pajak sudah ban-

\footnotetext{
Peter Mahmud Marzuki, Penelitian Hukum (Kencana Jakarta: Prenada Media Group, 2010), 96-97.

9 Ibid 137.
} 
yak di terapkan pada Negara-negara di dunia. Di Afrika Selatan penerapan Tax Amnesty dimulai pada tahun $1995 .{ }^{10}$ Pengampunan pajak pada saat itu hanya terbatas bagi pihak yang asetnya disimpan atau berada di luar negeri tetapi belum dikenakan pajak. Sedangkan India sudah terlebih dahulu melaksanakan Tax Amnesty yaitu pada tahun $1965 .{ }^{11}$ India melaksanakan program ini secara berkala yaitu empat sampai lima tahun sekali. ${ }^{12}$

Di Rusia, Tax Amnesty pertama kali diselenggarakan pada tahun 1993 dengan tujuan awal adalah untuk mengungkap pendapatan tersembunyi dari perusahaan-perusahaan di Rusia. ${ }^{13}$ Sampai saat ini sudah sebanyak 3 (tiga) kali pelaksanaan pengampunan pajak di Rusia yaitu diawali tahun 1993, kemudian berlanjut tahun 2007 dan selanjutnya di tahun 2017. ${ }^{14}$

Tax Amnesty di Indonesia pertama kali dilakukan pada tahun 1964 melalui Keputusan Presiden Nomor 5 Tahun 1964 tentang Peraturan Pengampunan Pajak. ${ }^{15}$ Pemerintah kembali melaksanakan program tersebut pada tahun 1984 dan setelah UU Tax Amnesty diberlakukan, dilaksanakan lagi pada tahun 2016 dan terakhir di tahun 2018. Pemerintah berencana akan menyelenggarakan kebijakan

\footnotetext{
${ }^{10}$ Mokhammad Khoirul Huda and Agus Yudha Hernoko, "Tax Amnesties in Indonesia and Other Countries: Opportunities and Challenges," Asian Social Science 13, no. 7 (2017): 58, http://www.ccsenet.org/journal/ index.php/ass/article/view/67248

$11 \quad$ Ibid., 59

12 Ibid.

${ }^{13}$ Igor A Mayburov and Anna P.Kireenko "Tax reforms and elections in modern Russia," Journal Of Tax Reform 4, no 1 (2018): 91, https://journals.urfu.ru/ index.php/jtr/article/view/3154

14 Ibid, 20

15 Op.Cit., 54
}

Tax Amnesty lagi pada tahun 2020-2021. ${ }^{16}$ Kebijakan ini bertujuan untuk memaksimalkan potensi pajak dengan memberikan rangsangan kesadaran diri berupa pembayaran uang tebusan bagi masyarakat untuk melaporkan harta wajib pajak baik didalam negeri maupun diluar negeri dengan menghapuskan sanksi administrasi perpajakan dan sanksi pidana di bidang perpajakan.

Kebijakan Tax Amnesty diatur didalam Undang-Undang Nomor 11 Tahun 2016 tentang Pengampunan Pajak. Menurut Pasal 1 angka 1, pengertian pengampunan pajak adalah:

"Pengampunan Pajak adalah penghapusan pajak yang seharusnya terutang, tidak dikenai sanksi administrasi perpajakan dan sanksi pidana di bidang perpajakan, dengan cara mengungkap Harta dan membayar Uang Tebusan sebagaimana diatur dalam Undang-Undang ini”.

Di dalam UU Tax Amnesty diatur bahwa subjek tax amnesty adalah setiap wajib pajak. Setiap wajib pajak berhak mendapatkan pengampunan pajak melalui pengungkapan hartanya dalam suatu Surat Pernyataan. Namun, terdapat pengecualian wajib pajak yang tidak diperkenankan mengikuti tax amnesty yaitu, wajib pajak yang sedang menjalani proses penyidikan dan berkas penyidikannya telah dinyatakan lengkap oleh Kejaksaan, lalu wajib pajak yang dalam proses peradilan, dan menjalani hukuman pidana atas Tindak Pidana di Bidang Perpajakan.

Menurut Pasal 1 angka (2) Undang-Undang Nomor 28 Tahun 2007 Tentang Keten-

\footnotetext{
${ }^{16}$ Redaksi DDTCNews, "Tiba-Tiba Sri Mulyani Wacanakan Tax Amnesty Jilid II, Ada Apa?, " DDTC News Trusted Indonesian Tax News Portal, Last modified 2019, accessed July 11, 2020, https:// news.ddtc.co.id/tiba-tiba-sri-mulyani-wacanakantax-amnesty-jilid-ii-ada-apa-16621
} 
tuan Umum dan Tata Cara Perpajakan (KUP), yang dimaksud wajib pajak adalah orang pribadi atau badan, meliputi pembayar pajak, pemotong pajak, dan pemungut pajak, yang memiliki hak dan kewajiban perpajakan yang diatur lebih khusus dalam perundang-undangan perpajakan. Pasal ini tidak menyebutkan klasifikasi WNA, hanya orang atau badan yang merupakan pembayar atau pemotong pajak. Namun, kita dapat memperjelas ketentuan wajib pajak menurut Tax Amnesty didalam UU Nomor 11 Tahun 2016 tentang Pengampunan Pajak (UU Tax Amnesty). Pasal 1 angka (2) peraturan ini menyatakan hal yang sama didalam KUP, bahwa wajib pajak adalah orang atau badan yang memiliki hak dan kewajiban perpajakan menurut ketentuan peraturan perpajakan. Memperjelas klausul tersebut, maka UU Tax Amnesty menjabarkan didalam Pasal 3, yang mengatur bahwa semua wajib pajak berhak mendapat pengampunan pajak. Wajib pajak sendiri adalah tergantung pada objek pajaknya. Oleh karena itu, untuk mengetahui siapa wajib pajak didalam Tax Amnesty, maka harus mengetahui dulu apa objek Tax Amnesty. Pasal 3 angka (5) mengatur bahwa kewajiban pajak yang dapat dilakukan pengampunan pajak adalah Pajak Penghasilan (PPh), Pajak Pertambahan Nilai (PPN), atau Pajak Pertambahan Nilai dan Pajak Penjualan Atas Barang Mewah (PPABW). Adanya pembatasan kewajiban pajak yang dapat dikenakan Tax Amnesty dapat membantu kita memahami siapa wajib pajak yang mengacu pada subjek pajak dari PPH, PPN atau PPN dan PPABW.

Objek Tax Amnesty menurut UU Tax Amnesty adalah pengampunan atas kewajiban perpajakan sampai dengan akhir tahun pajak terakhir, yang belum atau sepenuhnya belum terselesaikan oleh wajib pajak. Kewajiban perpajakan tersebut terdiri dari kewajiban Pajak Penghasilan, dan Pajak Pertambahan Nilai atau Pajak Pertambahan Nilai dan Pajak Penjualan Atas Barang Mewah.

\section{Warga Negara Asing (WNA)}

Warga Negara Asing (WNA) didalam UU Nomor 12 Tahun 2006 tentang Kewarganegaraan Republik Indonesia tidak disebutkan pengertian WNA, dan hanya menjelaskan pengertian WNI. Oleh karena itu dapat menggunakan a contrario untuk mendefinisikan WNA. Menurut Pasal 2 UU Nomor 12 Tahun 2006, yang dapat menjadi WNI adalah orang-orang bangsa Indonesia asli dan orang-orang bangsa lain yang disahkan dengan undang-undang sebagai warga negara. Penjelasan Pasal 2 peraturan tersebut menjelaskan bahwa yang dimaksud dengan "orang-orang bangsa Indonesia asli" adalah orang Indonesia yang menjadi Warga Negara Indonesia sejak kelahirannya dan tidak pernah menerima kewarganegaraan lain atas kehendak sendiri dan diperjelas dengan pengaturan menurut Pasal 4 tentang siapa saja yang termasuk WNI. Berdasarkan a contrario maka, WNA adalah orang-orang yang tidak memiliki unsur definisi sebagai WNI yaitu bukan berasal dari bangsa Indonesia asli dan tidak sesuai dengan kualifikasi pada Pasal 4.

\section{Kedudukan WNA didalam Tax Amnesty}

Pasal 3 UU Nomor 11 Tahun 2016 tentang Pengampunan Pajak mengatur bahwa semua wajib pajak berhak mendapat pengampunan pajak. Permasalahannya adalah apakah WNA termasuk wajib pajak? Menurut UU Nomor 28 Tahun 2007 yang dimaksud dengan wajib pajak adalah orang pribadi atau badan, meliputi pembayar pajak, pemotong pajak, dan pemungut pajak, yang mempunyai 
hak dan kewajiban perpajakan sesuai dengan ketentuan peraturan perundang-undangan perpajakan.

Penerapan Asas Domisili, Asas Sumber dan Asas Kebangsaan didalam UU Pajak Penghasilan (PPh) Nomor 36 Tahun 2008 tentang Pajak Penghasilan dapat digunakan untuk menganalisa kedudukan WNA didalam Tax Amnesty ${ }^{17}$ Didalam asas domisili yang tercantum didalam Pasal 2 angka (2), (3), (4) UU Nomor 36 Tahun 2008 tentang PPh yang mengatur bahwa, subjek pajak untuk PPh dibedakan menjadi dua yaitu subjek pajak dalam negeri dan subjek pajak luar negeri. Penggolongan subjek pajak tersebut didasarkan pada dimana subjek pajak bertempat tinggal. Subjek pajak dalam negeri digolongkan sebagai perorangan yang bertempat tinggal di Indonesia dan yang berada di Indonesia lebih dari 183 hari dalam jangka waktu 12 bulan atau yang dalam suatu tahun pajak berkeinginan untuk menetap di Indonesia. Selain itu juga dapat berupa badan yang didirikan atau berkedudukan di Indonesia, kecuali unit-unit tertentu dari badan pemerintah yang memenuhi kriteria. Sedangkan subjek pajak luar negeri menurut Pasal 2 ayat (4) adalah orang pribadi yang tidak berdomisili di Indonesia, orang pribadi yang berada di Indonesia paling lama 183 hari dalam kurun waktu 12 bulan. Selain itu juga berupa badan yang tidak didirikan dan tidak berkedudukan di Indonesia, yang menjalankan usaha atau melakukan kegiatan melalui bentuk usaha tetap di Indonesia. Didalam ayat 4 huruf (b) subjek pajak luar negeri juga dijelaskan dapat berupa orang pribadi yang tidak bertempat tinggal di Indonesia paling lama 183 hari dalam kurun waktu 12 bulan, dan badan yang

\footnotetext{
${ }^{17}$ Suparnyo, Hukum Pajak Suatu Sketsa Asas
} (Semarang: Pustaka Magister, 2012), 26 tidak didirikan dan tidak bertempat kedudukan di Indonesia, yang dapat menerima atau memperoleh penghasilan dari Indonesia tidak dari menjalankan usaha atau melakukan kegiatan berupa bentuk usaha tetap di Indonesia. Berdasarkan peraturan tersebut, maka dapat disimpulkan bahwa WNA yang sudah berada di Indonesia selama 183 hari merupakan wajib pajak dan harus memiliki NPWP.

Menurut asas sumber didalam Pasal 2 ayat (4) huruf b UU PPh diatur bahwa subjek pajak penghasilan ditentukan dari sumber penghasilan yang didapat. Apabila sumber penghasilan diperoleh atau diterima melalui bentuk usaha tetap yang berada atau berkedudukan di Indonesia, maka orang pribadi atau badan tersebut memiliki status sebagai pajak luar negeri. hal tersebut berakibat kedudukan badan usaha tetap menggantikan kedudukan orang pribadi atau badan sebagai subjek pajak luar negeri untuk dapat melaksanakan tanggung jawab perpajakan di Indonesia. Jika penghasilannya diperoleh tidak melalui bentuk usaha tetap, maka pertanggungjawaban perpajakannya ditanggung oleh subjek pajak luar negeri tersebut. Pemaparan tersebut menjelaskan bahwa WNA yang memiliki sumber penghasilan di Indonesia baik itu dalam bentuk badan usaha tetap ataupun tidak, maka dapat dikategorikan sebagai wajib pajak dan oleh karenanya Negara berhak memungut pajaknya.

Berdasarkan asas kebangsaan, asas ini memberikan jembatan kepada Negara dalam hal hak menarik pajak dengan kebangsaan wajib pajaknya. Asas ini dapat diartikan menjadi dua pengertian. Pertama, pengaertian aktif, artinya Negara berhak menarik pajak atas warga negaranya dimanapun mereka berada. Kedua pengertian pasif, artinya Negara berhak menarik pajak atas Warga Negara Asing 
(WNA) yang tinggal dinegaranya. Menurut pengertian pasif tersebut, WNA dapat digolongkan sebagai wajib pajak.

Berdasarkan analisa hukum terhadap ketiga asas tersebut, dapat disimpulkan bahwa WNA dikategorikan sebagai wajib pajak. Menurut UU Tax Amnesty bahwa subjek Tax Amnesty adalah semua wajib pajak. Oleh karena itu, maka WNA yang memenuhi syarat subjektif dan objektif dari peraturan perpajakan dikategorikan sebagai wajib pajak dan diperbolehkan mengikuti Tax Amnesty.

\section{Penerapan Tax Amnesty terhadap Warga Negara Asing (WNA) yang menikah den- gan Warga Negara Indonesia (WNI) \\ Pernikahan Beda Kewarganegaraan}

Setelah mengetahui pengertian WNI dan WNA dari pemaparan diatas, maka pembahasan selanjutnya untuk memperjelas rumusan masalah kedua adalah pengertian pernikahan beda kewarganegaraan. Indonesia telah merevisi UU Perkawinan yang lama dengan UU Nomor 16 Tahun 2019 tentang Perubahan Atas UU Nomor 1 Tahun 1974 tentang Perkawinan. Di dalam UU Perkawinan yang baru hanya mengubah beberapa pasal, sehingga pasal-pasal yang tidak diubah atau tidak dicantumkan didalam perubahan dianggap tetap berlaku didalam UU lama. Pernikahan beda kewarganegaraan menurut UU Nomor 1 Tahun 1974 tentang Perkawinan termasuk didalam arti perkawinan campuran. Pasal 57 mengatur bahwa perkawinan campuran adalah perkawinan yang dilangsungkan oleh dua orang yang berada di Indonesia dengan hukum yang berbeda, dikarenakan perbedaan kewarganegaraan yang salah satunya berkewarganegaraan Indonesia.

Di Indonesia banyak dijumpai perkaw- inan campuran Antara WNI dan WNA. Perjanjian Perkawinan menurut Pasal 29 UU Nomor 1 Tahun 1974 adalah perjanjian yang dilakukan antara dua orang yang akan atau sudah melangsungkan perkawinan yang berisi persetujuan bersama dalam bentuk perjanjian tertulis yang kemudian disahkan oleh pegawai pencatat perkawinan dan isinya berlaku bagi pihak ketiga tersangkut. Pengertian perjanjian kawin menurut Soetojo Prawirohamidjojo, adalah "Perjanjian kawin (huwelijks atau huwelijkse voorwaarden) adalah perjanjian yang dibuat oleh dua orang calon suami isteri sebelum dilangsungkannya perkawinan mereka, untuk mengatur akibat-akibat perkawinan yang menyangkut harta kekayaan". ${ }^{18}$ Menurut J. Andy Hartanto didalam bukunya, perjanjian perkawinan yang dibuat di dalam perkawinan campuran bertujuan untuk melindungi istri dari kemungkinan terjadinya tindakan tidak baik dari suami selama proses pengurusan harta kekayaan dalam perkawinan dan agar barang-barang yang dibawa baik suami ataupun istri sebelum menikah tidak bercampur sebagai harta persatuan. Perjanjian kawin juga harus dibuat dalam akta Notaris. Perjanjian kawin yang dibuat dihadapan Notaris memiliki kekuatan hukum karena akan memberikan kepastian hukum terhadap hak dan kewajiban suami istri menyangkut harta mereka. Hal tersebut penting dilakukan, karena perjanjian kawin memiliki akibat hukum yang luas termasuk terhadap faktor keuangan di

\footnotetext{
${ }^{18}$ R. Soetojo Prawirohamidjojo and Marthalena pohan, Hukum Orang dan Keluarga (Surabaya: Airlangga University Press, 2000), 74
} 
dalam rumah tangga. ${ }^{19}$

Perkawinan campuran memiliki beberapa akibat hukum jika dikaitkan UU Perkawinan, UU Kewarganegaraan, dan UU Keimigrasian, maka akibat hukum perkawinan campuran Antara lain:

1) Pasangan perkawinan campuran dapat memperoleh kewarganegaraan dari pasangannya atau kehilangan kewarganegaraannya sesuai UU Nomor 12 Tahun 2006 (Pasal 58 UU Perkawinan jo. UU Nomor 12 Tahun 2006);

2) Jika WNA tidak berkenan atau belum mendapat kewarganegaraan Indonesia, maka WNA dapat memperoleh Izin Tinggal Tetap atas dasar perkawinan campuran (Pasal 54 ayat (1) huruf b dan c UU Nomor 6 Tahun 2011 jo. PP Nomor 31 Tahun 2013);

3) Perjanjian perkawinan berakibat hukum pada pemisahan harta gono-gini, WNI tidak akan bisa memiliki hak atas tanah tanpa perjanjian perkawinan.

Jika perkawinan campuran dilakukan tanpa ada perjanjian kawin atau perjanjian pisah harta, maka sesuai dengan pengaturan didalam UU Perkawinan, berlakulah percampuran harta. Di dalam kasus, WNA dan WNI menikah, dan WNI ini ingin membeli tanah dengan status hak milik, hal ini tidak dapat dilakukan manakala pernikahan WNI ini tidak dengan perjanjian kawin karena pernikahan campuran tanpa perjanjian kawin berarti hartanya bercampur sehingga WNA berhak atas harta tersebut. ${ }^{20}$ Pasal 21 ayat (2) Undang-Undang

\footnotetext{
19 J Andy Hartanto, Hukum Harta Kekayaan Perkawinan Menurut "Burgerlijk Wetbook" dan Undang-Undang Perkawinan (Yogyakarta. Laksbang Grafika, 2012), 24

${ }^{20}$ Adoe, Andreas, "Pembelian Tanah Suami Istri dan Sengketa Pajak," Tax Research and Solution for
}

Pokok Agraria mengatur bahwa subjek hak milik adalah Warga Negara Indonesia dan badan yang ditentukan didalam peraturan ini. Oleh karena itu, maka status hak atas tanah berupa hak milik tidak dapat dimiliki oleh WNA. ${ }^{21}$ Begitu juga dengan penghasilan WNA yang diperoleh di Indonesia yang merupakan harta yang dimiliki didalam perkawinan bersama WNI. Harta-harta perkawinan campuran harus dipisahkan untuk memberikan kejelasan didalam proses pengurusan hak dan pelaksanaan kewajiban perpajakan termasuk juga tax amnesty.

Sebagai contoh kasus putusan Mahkamah Konstitusi Nomor 69/PUU$\mathrm{XIII} / 2015$ tentang protes seorang istri berkewarganegaraan Indonesia yang bersuami WNA karena larangan memiliki hak atas tanah berstatus Hak Milik. Di dalam putusan tersebut pemohon mengajukan peninjauan kembali terkait hak kewarganegaraannya untuk memiliki asset di tanah kelahirannya. Namun, Majelis Hakim berpendapat bahwa hak tersebut tidak dapat dikabulkan mengingat status perkawinannya adalah perkawinan campuran dengan suami berkewarganegaraan asing yang tidak memiliki perjanjian perkawinan. Pertimbangan tersebut didasari jiwa nasionalisme yang dijunjung dalam UU Pokok Agraria (UUPA). Putusan tersebut akhirnya melahirkan putusan bahwa perjanjian perkawinan dapat dibuat tidak han-

Indonesia (Taxnesia), Last modified 2016, accessed July, 1 2020, http://www.taxnesia.com/2016/07/05/ pembelian-tanah-suami-istri-dan-pajak/

${ }^{21}$ Mira Novana Ardani, "Kepemilikan Hak Atas Tanah Bagi Warga Asing di Indonesia," Jurnal Law Reform, Fakultas Hukum Universitas Diponegoro 13 no. 2 (2017) : 208, https://ejournal.undip.ac.id/index.php/ lawreform/article/view/16156 
ya sebelum/saat perkawinan akan dilangsungkan tetapi juga dapat dibuat sepanjang pernikahan berlangsung, dengan demikian WNI dapat memiliki asset berupa tanah atau bangunan dengan status Hak Milik.

\section{Penerapan Tax Amnesty bagi harta WNA didalam Perkawinan Campuran}

Perjanjian perkawinan memberikan dampak yang besar bagi para pelaku perkawinan campuran. Setelah adanya Putusan MK Nomor 69 Tahun 2015, Perjanjian Perkawinan dapat dibuat tidak hanya sebelum perkawinan tetapi juga pada saat perkawinan berlangsung. Adanya perjanjian perkawinan dapat membantu memilah hak dan kewajiban WNA dan WNI terkait harta bersama yang diperoleh selama perkawinan. ${ }^{22}$ Harta-harta yang diperoleh harus dilaporkan kepada Negara terkait kewajiban sebagai subjek pajak. Jika seorang sudah memenuhi syarat subjektif sebagai wajib pajak, maka harta dan perolehannya harus dilaporkan sesuai dengan sifat pajaknya. ${ }^{23}$ Tidak terkecuali WNA yang menikah dengan WNI dan menetap di Indonesia atau memperoleh penghasilan di Indonesia wajib membayar pajak. Penerapan pajak bagi suami istri diatur didalam Pasal 8 ayat (1) UU Nomor 36 Tahun 2008 tentang Pajak Penghasilan mengatur bahwa seluruh penghasilan atau

\footnotetext{
${ }^{22}$ Aislie Anantama Septiawan, "Perjanjian Perkawinan Pada Perkawinan Campuran Dalam Kepemilikan Tanah Di Indonesia," Lambung Mangkurat Law Journal 2, no. 1 (2017): 67, https://amlaj.ulm.ac.id/ web/index.php/abc/article/view/32/pdf_4

${ }^{23}$ Heriani, Fitri N, "Apakah WNA boleh ikut Tax Amnesty?," Hukum Online.com Last modified 2016, accessed July 1, 2020, https://www.hukumonline. $\mathrm{com} /$ berita/baca/lt57ee4b8fabc87/apakah-wna-bolehikut-tax-amnesty-ini-penjelasannya/
}

kerugian wanita yang telah kawin pada awal tahun pajak atau pada awal bagian tahun pajak, begitu pula kerugiannya yang berasal dari tahun-tahun sebelumnya yang belum dikompensasikan menurut Pasal 6 ayat (2) dianggap sebagai penghasilan atau kerugian suaminya, kecuali penghasilan tersebut semata-mata diterima atau diperoleh dari satu pemberi kerja yang telah dipotong pajak berdasarkan ketentuan Pasal 21 dan pekerjaan tersebut tidak ada hubungannya dengan usaha atau pekerjaan bebas suaminya atau keluarga lainnya. Menurut Pasal tersebut menegaskan bahwa keluarga merupakan satu kesatuan ekonomis yang artinya adanya kerugian dan penghasilan dari seluruh anggota keluarga dihitung sebagai satu kesatuan untuk dapat dihitung pengenaan pajaknya oleh kepala keluarga, kecuali untuk kondisi tertentu pengenaan pajak dilakukan terpisah.

Sedangkan Pasal 8 ayat (2) mengatur tentang kondisi perkawinan tertentu dan kewajiban pajaknya. Penghasilan suami istri dikenai pajak terpisah apabila suami istri telah bercerai sesuai putusan hakim, adanya perjanjian pisah harta yang merupakan persetujuan suami istri, dan adanya perjanjian bahwa istri memilih untuk melakukan kewajiban perpajakan terpisah dari suami dibuktikan dengan perjanjian tertulis. Menurut penjelasan peraturan tersebut, jika suami istri memiliki perjanjian pisah harta maka kewajiban perpajakannya dihitung berdasarkan penjumlahan penghasilan netto suami/istri dan masing-masing memikul beban pajak sebanding dengan nilai penghasilan netto. Jadi disini dapat dilihat ada pemisahan kewajiban perpajakan antara suami istri yang memiliki perjanjian pisah harta. 
Hal tersebut dapat disimpulkan apabila suami/istri yang melakukan perkawinan campuran dan ingin mengikuti tax amnesty maka pelaporannya dilakukan masingmasing dengan menunjukkan akta perjanjian perkawinannya. Mengenai tax amnesty, suami/istri WNA/WNI dapat mengikuti tax amnesty atas harta yang menjadi miliknya baik yang diperoleh sebelum menikah maupun setelah menikah dengan perjanjian pisah harta.

Bagi WNA yang melakukan perkawinan campuran dan ingin memohon pengampunan pajak, maka WNA tersebut dapat menunjukkan bukti akta perjanjian perkawinan dan laporan hartanya. Misalkan WNA yang berpenghasilan di Indonesia dan memiliki asset berupa rumah atau tanah yang disewakan di Negara asalnya, maka WNA wajib melaporkan hasil sewa asset tersebut sebagai kewajiban pajaknya apabila di negaranya belum dilaporkan kewajiban pajaknya. Bagi WNA/WNI yang menikah tanpa adanya perjanjian pisah harta, maka berlaku asas kewarganegaraan, dimanapun sumber pendapatannya tetap harus melaporkan untuk pajak penghasilan sebagai dasar pengenaan tax amnesty.

\section{PENUTUP}

Berdasarkan asas-asas di dalam hukum pajak maka Warga Negara Asing (WNA) yang berada di Indonesia selama 183 hari tergolong sebagai wajib pajak. Berdasarkan KUP, maka wajib pajak harus memiliki NPWP sebagai bukti statusnya sebagai subjek pajak. Di dalam UU Tax Amnesty, yang diperbolehkan mengikuti pengampunan pajak adalah semua Wajib pajak. Jika melihat berdasarkan analisa hukum tersebut, maka WNA yang telah memiliki NPWP di perbolehkan mengikuti tax amnesty.

Di dalam Perkawinan campuran antara WNA dan WNI sebaiknya memiliki perjanjian perkawinan sebagai alas hukum kepemilikan hak penguasaan harta masing-masing. Hal tersebut dikarenakan pentingnya perjanjian perkawinan di berbagai aspek hukum dalam perkawinan campuran. Salah satu contohnya dalah ketika pembayaran pajak, pelaku perkawinan campuran akan dimintai bukti kesediaan mengikuti NPWP suami/istri atau bukti pemisahan perpajakan. Jika tidak memiliki perjanjian perkawinan, maka si istri akan diikutkan NPWP suami. Hal ini juga berpengaruh pada hak mengikuti pengampunan pajak. Adanya perjanjian perkawinan memudahkan penghitungan kewajiban pajak atas asset WNA, sehingga WNA dapat memohonkan pengampunan pajak atas harta baik yang berasal dari penghasilannya di Indonesia maupun atas harta hasil sewa bangunan yang ia miliki di Negara asalnya. Pelaporannya berdasarkan pengaturan Pasal 8 ayat (2) UU Pajak Penghasilan dengan melampirkan perjanjian pisah harta dan perjanjian pemisahan pelaksanaan kewajiban perpajakan dari suaminya.

Masih banyak perselisihan tentang harta bersama terkait dengan pelaksanaan kewajiban perpajakan dan tax amnesty. Hal ini dikarenakan banyak subjek pajak belum memahami tentang pentingnya perjanjian pisah harta karena masyarakat Indonesia yang kental dengan unsur budaya dan sosialnya masih mengikuti persatuan harta setelah menikah. Namun tidak dengan perkawinan campuran. Pada kasus WNA yang menikah dengan WNI disarankan tetap melakukan perjanjian pisah harta agar memudahkan dalam pengurusan pajak dan permohonan pengampunan pajak.

Penulis menyarankan pemerintah memi- 
liki sumber penyampaian informasi tentang tax amnesty tidak hanya di instansi Direktorat Jenderal Pajak tetapi juga di instansi lain seperti Dinas Kependudukan, Kantor Pencatatan Perkawinan, Keimigrasian dan layanan publik lainnya. Informasi yang lengkap akan membuat target pendapatan pajak dari tax amnesty maksimal dan dapat mengakomodir WNA/WNI yang akan melakukan perkawinan campuran untuk memiliki pengetahuan dan pemahaman yang jelas terkait perjanjian pisah harta sebagai landasan mengikuti program tax amnesty.

\section{BIBLIOGRAFI}

\section{Buku}

J Andy Hartanto. Hukum Harta Kekayaan Perkawinan Menurut "Burgerlijk Wetbook” dan Undang-Undang Perkawinan. Yogyakarta: Laksbang Grafika, 2012.

R. Soetojo Prawirohamidjojo, and Marthalena Pohan. Hukum Orang dan Keluarga. Surabaya: Airlangga University Press, 2000.

Rochmat Soemitro. Asas dan Dasar-Dasar Perpajakan. Cetakan I. Bandung: PT. Eresco, 1990.

Rochmat Szzoemitro. Asas dan Dasar Perpajakan. Cetakan II. Bandung: PT Refika Aditama, 1998.

Suparnyo. Hukum Pajak Suatu Sketsa Asas. Semarang: Pustaka Magister, 2012.

\section{Jurnal}

Anantama, Septiawan, Aislie. "Perjanjian Perkawinan Pada Perkawinan Campuran Dalam Kepemilikan Tanah Di Indonesia." Lambung Mangkurat Law Journal 2, no. 1 (2017): 67. https://lamlaj.ulm. ac.id/web/index.php/abc/article/view/32/ pdf_4

Ardani, Mira Novana. "Kepemilikan Hak
Atas Tanah Bagi Warga Asing di Indonesia." Jurnal Law Reform Fakultas Hukum Universitas Diponegoro 13, no. 2 (2017): 208. https://ejournal.undip.ac.id/ index.php/lawreform/article/view/16156

Huda, Mokhammad Khoirul and Agus Yudha Hernoko. "Tax Amnesties in Indonesia and Other Countries: Opportunities and Challenges." Asian Social Science 13, no.7 (2017): 58. http://www.ccsenet.org/ journal/index.php/ass/article/view/67248

Mayburov, Igor A., and Anna P. Kireenko. "Tax reforms and elections in modern Russia." Journal Of Tax Reform 4, no 1 (2018) : 91. https://journals.urfu.ru/index.php/jtr/article/view/3154

Mulyati, Dewi. "Pelaksanaan Perjanjian Pemisahan Harta Dalam Perkawinan Warga Negara Indonesia Dengan Warga Negara Asing." Jurnal IUS Kajian Hukum dan Keadilan, Fakultas Hukum Universitas Mataram 5, no 2 (2017): 9. http://jurnalius.ac.id/ojs/index.php/jurnalIUS/article/view/460/

Sari, Ramadhani Indah and Dian Anita Nuswantara. "The Influence of Tax Amnesty Benefit Perception to Taxpayer Compliance". Jurnal Dinamika Akuntansi, 9, no 2 (2017): 176-183. https://journal.unnes.ac.id/nju/index.php/jda/article/ view/11991/7455

Titik Setyaningsih and Antin Okfitasari, "Mengapa Wajib Pajak Mengikuti Tax Amnesty (Studi Kasus di Solo). " Stiesia: Jurnal Ekonomi dan Keuangan 20, no. 4 (2016): 430. https://ejournal.stiesia. ac.id/ekuitas/article/view/2012/38

\section{Internet}

Adoe, Andreas. "Pembelian Tanah Suami Istri dan Sengketa Pajak." Tax Research and Solution for Indonesia (Taxnesia). Last 
modified 2016. Accessed July 1, 2020. http://www.taxnesia.com/2016/07/05/ pembelian-tanah-suami-istri-dan-pajak/

Heriani, Fitri N. "Apakah WNA boleh ikut Tax Amnesty?" Hukum Online.com. Last modified 2016. Accessed July 1, 2020. https://www.hukumonline.com/berita/ baca/lt57ee4b8fabc87/apakah-wna-boleh-ikut-tax-amnesty-ini-penjelasannya/

Redaksi DDTCNews. "Tiba-Tiba Sri Mulyani Wacanakan Tax Amnesty Jilid II, Ada Apa?" DDTC News Trusted Indonesian Tax News Portal. Last modified 2019. Accessed July 11, 2020. www. news. ddtc.co.idhttps://news.ddtc.co.id/tiba-tiba-sri-mulyani-wacanakan-tax-amnestyjilid-ii-ada-apa-16621

Yudanto, Noor, Andy Johan Prasetyo, Fadhil Nugroho, and Putu Utami Ardarini Sadha. "Survey Nasional Tenaga Kerja Asing Di Indonesia Tahun 2009." Bank Indonesia, Bank Sentral Republik Indonesia. Last Modified 2010. Accessed August 1, 2020. https://www.bi.go.id/id/publikasi/ lain/lainnya/Pages/SurveiTKAIndonesia_09.aspx

\section{Peraturan Perundang-undangan}

Undang-Undang Nomor 5 Tahun 1960 tentang Peraturan Dasar Pokok-Pokok Agraria

Undang-Undang Nomor 1 Tahun 1974 tentang Perkawinan sebagaimana telah diubah dengan Undang

Undang-Undang Nomor 12 Tahun 2006 tentang Kewarganegaraan Republi Indonesia Undang-Undang Nomor 28 Tahun 2007 tentang Ketentuan Umum dan Tata Cara Perpajakan

Undang-Undang Nomor 36 Tahun 2008 tentang Pajak Penghasilan

Undang-Undang Nomor 42 Tahun 2009 tentang Pajak Pertambahan Nilai

Undang-Undang Nomor 6 Tahun 2011 tentang Keimigrasian

Undang-Undang Nomor 11 Tahun 2016 tentang Pengampunan Pajak

Undang-Undang Nomor 16 Tahun 2019 tentang Perkawinan 